\title{
The Physical Properties of By-Product Proportion in Rice Flour-Based Facial Scrub
}

\author{
Maspiyah $^{1 *}$, Suhartiningsih ${ }^{1}$ and Kusniah, Naim ${ }^{1}$ \\ ${ }^{1}$ Cosmetology of Home Economic Department, Universitas Negeri Surabaya, Surabaya, Ketintang Street 60231, \\ Indonesia \\ *Corresponding author. Email: maspiyah@unesa.ac.id
}

\begin{abstract}
Sustainable development of under-utilized by-product commodities such as rice, potato, and orange which has high productivity in Indonesia is necessary. Rice has been known to be used in the traditional cosmetic application and can be valued-added by several by-products such as potato and orange peel incorporation. The peel which rich in antioxidants was formed into flour to make it easier to blend into rice flour-based face scrub. This study was to analyze the effect of added potato and orange peel flour proportion on rice flour-based face scrub's physical properties. The experiment was conducted on four proportion levels to determine aroma, texture, stickiness, color, and preference of rice flourbased face scrub. Data were obtained from 30 panels observation and analyzed with one-way ANOVA and Duncan test on a significant level $<0,05$. The result showed that: 1) potato and orange peel flour proportion affected on aroma, texture, stickiness, color, and preference of rice flour-based face scrub; 2) the best product was rice flour face scrub with the proportion of potato and orange peel flour (PPF: OPF) on 4:3. This study will compile current findings on by-product utilization as a new cosmetic innovation with an economic and environmentally friendly approach.
\end{abstract}

\section{Keywords: by-product, potato peel flour, orange peel flour, cosmetic ethnology}

\section{INTRODUCTION}

Rice is the second most important cereal crop for more than half of the world's population, no exception Indonesia has high productivity because of its role as a staple food. The production of rice is increasing from 2013 to 2017 with the production reaches 81 million tons [1]. The number of research has studied rice benefits namely good nutritional value, resistance to high blood pressure, dysentery, heart diseases used in skincare. In the Indian subcontinent, rice water is duly prescribed by ayurvedic practitioners as an effective ointment to cool off inflamed skin surfaces [5]. Rice also processed into flour and has been implicated since ancient times by Egyptians and Greeks, [2] while Malaysian and Indonesian women used rice in a form of cooling face mask where the rice is soaked for three months or until the rice grains fully dissolved [3] [4]. The application of dried powdered rice is recommended for skin ailments [5].

Besides the use of rice, the women in several regions in the world have developed a rich ethnomedical tradition. The traditional herbal preparations that they passed down from generation to generation to cure skin infections and other diseases by utilized plants leave, root, and discharged parts such as peel. The several plants they used includes dried fruit peel of banana (Musa spp.) for lips blackness and leprosy infected skin, dried lemon peel (Citrus Limon) to remove the tartar of tooth, and soapberry (Sapindus Saponaria) for hair growth and shine [7] [8] [10]. Apart from traditional ethnic-cosmetic applications of local herbs, Afzal et al stated that efforts are in progress to formulate and develop skincare products based on these natural resources by-products, termed as herbal cosmetics [9]. Other natural resources that can be used in herbal cosmetics are potato and orange, with the correlation of its high productivity level in Indonesia and can be caused by environmental concern due to its microbial spoilage [14] [11] [12].

Potato and orange is a horticulture commodity which significantly increases in productivity level in these past 6 years.

The productivity of potato has increased significantly from 2013 to 2018 from $160,18 \mathrm{Ku} / \mathrm{Ha}$ to $187,06 \mathrm{Ku} / \mathrm{Ha}$ [14] and orange is higher than potato, it is $309,20 \mathrm{Ku} / \mathrm{Ha}$ to $404,41 \mathrm{Ku} / \mathrm{Ha}$. According to the Indonesian Ministry of agriculture, orange is the third-highest fruit 
commodities production at the national level with reach 20 million tons each year [14]. As it is also stated by Wu that sweet orange (Citrus Sinensis) is the major fruit in the citrus group constituting up to $70 \%$ of the total citrus production and consumption [11]. Several studies have reported the potential of these by-products application in terms of the herbal cosmetic and pharmaceutical field. The potential use of essential oils from citrus waste as anti-inflammatory and antimicrobial agents in cosmetics has been reported by Yang et al [13]. While lactic acid that generally used in the cosmetic and pharmaceutical applications can be extracted from potato peel [12]. Therefore, there will be a necessary utilization of this large amount of by-product derived from its annual high productivity level into a cosmetic appliance such as face scrub. The face scrub is granules that are not foaming which serves to remove dead skin cells and further optimize the facial cleansing process [15]. Various brands of beauty products have issued products in the form of face scrubs with a variety of different scents and functions. However, most of these products are made from chemicals that can cause irritation or allergic skin on some people's faces. The demand for herbal and natural based cosmetic is increasing rapidly nowadays due to ease of availability, good results as well as minimum side effects [16] [17].

Potato and orange peel scrubs require to be transformed into powder or flour base to make it easier to use and apply. The authors chose rice flour as the basis for a face scrub to be made. This study aimed at evaluating the effect of several added proportion of potato peel flour (PPF) and orange peel flour (OPF) on the physical properties of rice flour-based face scrubs. The following physical properties which evaluate include aroma, color, texture, stickiness, and preference. This study carried out to sustain environmental management due to the reuse of consumption and industrial discharged by-product. This study will compile current findings on by-product utilization as a new cosmetic innovation with an economic and environmentally friendly approach.

\section{MATERIALS AND METHODS}

\subsection{Ingredients and equipment}

The materials used in this study obtained from the local market in Surabaya, Indonesia. Rice flour used in this study is commercial rice flour with the brand 'Rose brand' which directly bought in the local market. Potato used is Solanum Tuberosum $\mathrm{L}$ and orange type used is sweet orange (Citrus Sinensis), both ingredients are peeled and discharged from its flesh.

The equipment used in this study provided in the Laboratory Cosmetology department of Universitas Negeri Surabaya. To make facial scrub the equipment is needed includes kitchen scale, knife/cutter, small bowl, stainless steel spoon, tray, chopper/blender, rubber spatula, jar, and sieve.

\subsection{The Production of $P P F$ and $O P F$}

By product raw material in this study was produced through a series of procedures that begin with the peeled potato and wash thoroughly. Cut potato peel into small pieces then dried potato peel under the sun for 7 days. Potato peel that has dried and then ground using a blender. If there is still a rough in it, repeat the ground step and sifted using a sieve no. 80 . The same procedures also applied to orange peel. After doing all of the procedures, keep the flour in a plastic container in dry and tightly closed conditions.

\subsection{The Production of Facial Scrub}

Facial scrub was produced with rice flour-based and through a series of procedures that begin with add $8 \mathrm{~g}$ rice flour in a plastic bowl. Mix rice flour with PPF and OPF with the several proportion values. Mix thoroughly and put the mixture in a plastic container. Keep it in a cool and dry place for the longer shelf-life. Before use, the mixture must be added with $9 \mathrm{~g}$ aqua dest and stir it until mix well. Make sure face is in clean condition and washed with a facial wash before using the facial scrub

\subsection{Experiment design}

The independent variable in this study was the proportion of PPF and OPF in several values X1= $(6: 1), X 2=(5: 2)$, $\mathrm{X} 3=(4: 3), \mathrm{X} 4=(3: 4)$. The dependent variable in this study was the physical properties of facial scrub are aroma, color, texture, stickiness, and panels preferences. The experiment design carried out in this study is a single factor design. The four proportion of PPF and OPF as shown in Table 1 below

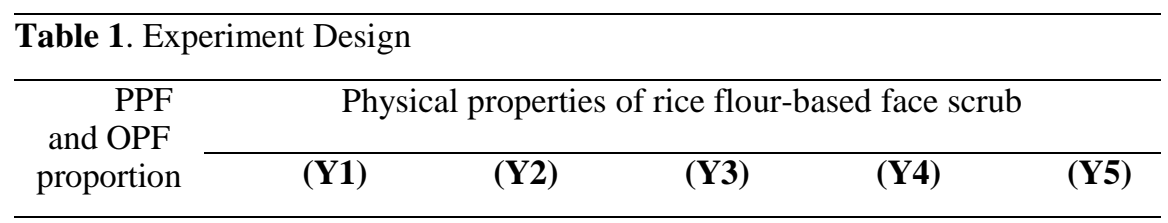




\begin{tabular}{rrrrrr}
\hline $\mathbf{X 1}$ & $\mathrm{Y} 1 \mathrm{X} 1$ & $\mathrm{Y} 2 \mathrm{X} 1$ & $\mathrm{Y} 3 \mathrm{X} 1$ & $\mathrm{Y} 4 \mathrm{X} 1$ & $\mathrm{Y} 5 \mathrm{X} 1$ \\
\hline $\mathbf{X 2}$ & $\mathrm{Y} 1 \mathrm{X} 2$ & $\mathrm{Y} 2 \mathrm{X} 2$ & $\mathrm{Y} 3 \mathrm{X} 2$ & $\mathrm{Y} 4 \mathrm{X} 2$ & $\mathrm{Y} 5 \mathrm{X} 2$ \\
\hline $\mathbf{X 3}$ & $\mathrm{Y} 1 \mathrm{X} 3$ & $\mathrm{Y} 2 \mathrm{X} 3$ & $\mathrm{Y} 3 \mathrm{X} 3$ & $\mathrm{Y} 4 \mathrm{X} 3$ & $\mathrm{Y} 5 \mathrm{X} 3$ \\
\hline $\mathbf{X} 4$ & $\mathrm{Y} 1 \mathrm{X} 4$ & $\mathrm{Y} 2 \mathrm{X} 4$ & $\mathrm{Y3X} 4$ & $\mathrm{Y} 4 \mathrm{X} 4$ & $\mathrm{Y} 5 \mathrm{X} 4$
\end{tabular}

Abbreviation:

$\mathrm{X} 1: 6 \mathrm{~g}$ PPF, $1 \mathrm{~g}$ OPF

$\mathrm{X} 2: 5 \mathrm{~g}$ PPF, $2 \mathrm{~g}$ OPF

$\mathrm{X} 3: 4 \mathrm{~g}$ PPF, $3 \mathrm{~g}$ OPF

$\mathrm{X} 4: 3 \mathrm{~g}$ PPF, $4 \mathrm{~g}$ OPF

Y1 : Aroma of rice flour-based face scrub

Y2 : Color of rice flour-based face scrub

Y3 : Texture of rice flour-based face scrub

Y4 : Stickiness of rice flour-based face scrub scrub

Y5 : Panels preferences of rice flour-based face

\subsection{Data Collection and Analyzation}

The data collection technique was carried out with observation by 30 panels, consisted of 5 lecturers and 25 students majoring in the Cosmetology study program of Universitas Negeri Surabaya. The observation instrument used was a questionnaire with several observed aspects in the final result of the facial scrub product includes aroma, texture, stickiness, color, and preferences. Data collection was conducted in the Home Economics Department, Engineering Faculty, Universitas Negeri Surabaya in June 2019. Data which has collected then analyzed with one way ANOVA in significant value $<0.05$. If the results show that there was a significant influence, a further test will be performed with the Duncan test.

\section{RESULTS AND DISCUSSION}

\subsection{Descriptive Analysis of Mean Value of Rice Flour-Based Facial Scrub's Physical Properties}

The mean value obtained from data collection presented in Figure 1. The result showed the range mean value from 1.6 to 3.63 which the lowest mean value obtained from $\mathrm{X} 1$ final product in the aspect of panel's preference and the highest mean value obtained from X3 final product's texture.

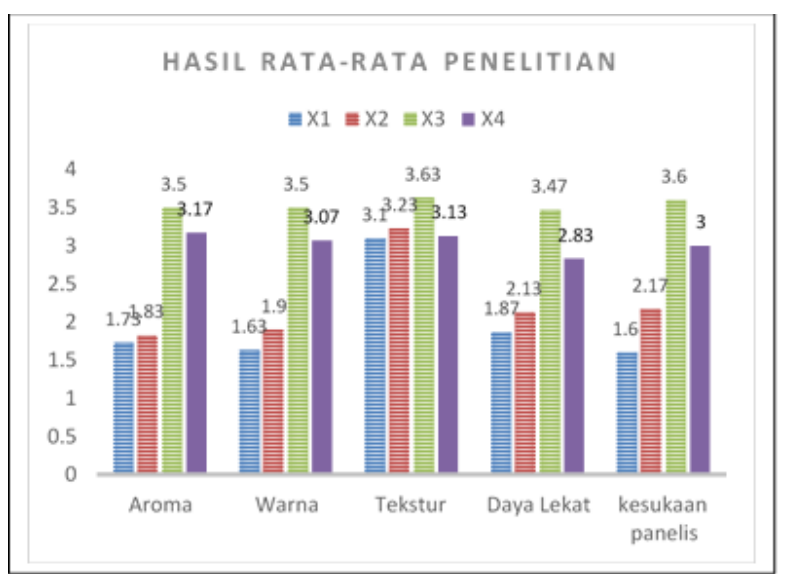

Fig 1. Mean Value of Facial Scrub Physical Properties

According to Figure 1., the proportion of PPF and OPF resulted in rice flour-based facial scrub's best aroma in X3 (4 g PPF: 3 g OPF) which obtained the highest mean value 3.5. Meanwhile, the lowest mean value was 1.73 which obtained from X1 (6 g PPF: $1 \mathrm{~g}$ OPF). Based on the result, it is showed that the orange peel flour amount in the proportion with potato peel flour contributed to facial scrub's aroma and the slight amount of OPF will result in the lowest mean value of facial scrub's aroma. The proportion of PPF and OPF resulted in rice flourbased facial scrub's best color in X3 (4 g PPF: $3 \mathrm{~g}$ OPF) which obtained the highest mean value 3.5. Meanwhile, the lowest mean value was 1.63 which obtained from X1 (6 g PPF: $1 \mathrm{~g}$ OPF). Based on the result, it is showed that the orange peel flour amount in the proportion with PPF contributed to facial scrub's color and the slight amount of OPF will result in the lowest mean value of facial scrub's color. Besides, the highest mean value of rice flour-based facial scrub's texture was 3,63 which derived from X3 (4 g PPF: $3 \mathrm{~g}$ OPF) proportion and the lowest mean value of rice flour-based facial scrub's texture was 3.1 and derived from X1 (6 g PPF: $1 \mathrm{~g}$ OPF) proportion. Based on the result, it is showed that the orange peel flour amount in the proportion with potato peel flour contributed to facial scrub's texture and the slight amount of OPF will result in the lowest mean value of facial scrub's texture.

According to Figure 1., the proportion of PPF and OPF resulted in rice flour-based facial scrub's best stickiness aspect from X3 (4 g PPF: $3 \mathrm{~g}$ OPF) proportion which obtained the highest mean value 3.47 . Meanwhile, the lowest mean value was 1.87 which derived from X1 (6 g PPF: $1 \mathrm{~g}$ OPF) proportion. Based on the result, it is showed that the orange peel flour amount in the 
proportion with potato peel flour contributed to facial scrub's stickiness and the higher amount of PPF will result in the lowest mean value of facial scrub's stickiness. In addition, the highest mean value of rice flour-based facial scrub's preferences was 3,6 which derived from X3 (4 g PPF: $3 \mathrm{~g}$ OPF) proportion and the lowest mean value of rice flour-based facial scrub's preference was 1.6 and derived from X1 (6 g PPF: $1 \mathrm{~g}$ $\mathrm{OPF}$ ) proportion. Based on the result, it is showed that the orange peel flour amount in the proportion with potato peel flour contributed to facial scrub's preference and the slight amount of OPF will result in the lowest mean value of facial scrub's preference.

\subsection{The effect of PPF and OPF Proportion on Rice Flour-Based Facial Scrub's Physical Properties}

The analytical result with one-way ANOVA to determine the effect of PPF and OPF proportion on rice flour-based facial scrub's physical properties includes color, texture, aroma, stickiness, and panel's preferences displayed in Table 2. The results showed that the proportion of PPF and OPF in different amounts affected all of the rice flourbased facial scrub's physical properties. Therefore, further Duncan test is performed to determine the mean value differences between the proportion amounts present in Table 3 .

Table 2. One-way ANOVA result of the effect of PPF and OPF proportion on rice flour facial scrub's physical properties

\begin{tabular}{|c|c|c|c|c|c|c|}
\hline $\begin{array}{l}\text { Physical } \\
\text { properties }\end{array}$ & & $\begin{array}{l}\text { Sum of } \\
\text { Squares }\end{array}$ & Df & $\begin{array}{l}\text { Mean } \\
\text { Square }\end{array}$ & $\mathrm{F}$ & Sig. \\
\hline \multirow{2}{*}{ Aroma } & Between Groups & 73,892 & 3 & 24,631 & 53,206 & ,000 \\
\hline & Within Groups & 53,700 & 116 & ,463 & & \\
\hline \multirow[b]{2}{*}{ Color } & Between Groups & 72,892 & 3 & 24,297 & 53,145 &, 000 \\
\hline & Within Groups & 53,033 & 116 & ,457 & & \\
\hline \multirow{2}{*}{ Texture } & Between Groups & 5,758 & 3 & 1,919 & 4,111 & ,008 \\
\hline & Within Groups & 54,167 & 116 & ,467 & & \\
\hline \multirow{2}{*}{ Stickiness } & Between Groups & 46,758 & 3 & 15,586 & 28,002 & ,000 \\
\hline & Within Groups & 64,567 & 116 & ,557 & & \\
\hline \multirow{2}{*}{ Preference } & Between Groups & 70,425 & 3 & 23,475 & 61,102 & ,000 \\
\hline & Within Groups & 44,567 & 116 & ,384 & & \\
\hline
\end{tabular}

Table 3. Duncan Test Result of Rice Flour Based Facial Scrub

\begin{tabular}{|c|c|c|c|c|c|}
\hline \multirow{2}{*}{$\begin{array}{c}\text { Physical } \\
\text { properties }\end{array}$} & \multirow{2}{*}{ Substitution } & \multicolumn{4}{|c|}{ Subset for alpha $=0.05$} \\
\hline & & 1 & 2 & 3 & 4 \\
\hline \multirow{4}{*}{ Aroma } & $\mathrm{X} 1$ & 1,73 & & & \\
\hline & $\mathrm{X} 2$ & 1,83 & & & \\
\hline & $\mathrm{X} 4$ & & 3,17 & & \\
\hline & $\mathrm{X} 3$ & & 3,50 & & \\
\hline \multirow{4}{*}{ Color } & $\mathrm{X} 1$ & 1,63 & & & \\
\hline & $\mathrm{X} 2$ & 1,90 & & & \\
\hline & $\mathrm{X} 4$ & & 3,07 & & \\
\hline & X3 & & & 3,50 & \\
\hline
\end{tabular}


Table 3. Duncan Test Result of Rice Flour Based Facial Scrub

\begin{tabular}{|c|c|c|c|c|c|}
\hline \multirow{2}{*}{$\begin{array}{l}\text { Physical } \\
\text { properties }\end{array}$} & \multirow{2}{*}{ Substitution } & \multicolumn{4}{|c|}{ Subset for alpha $=0.05$} \\
\hline & & 1 & 2 & 3 & 4 \\
\hline \multirow{4}{*}{ Texture } & $\mathrm{X} 2$ & 3,23 & & & \\
\hline & X4 & 3,13 & & & \\
\hline & $\mathrm{X} 1$ & 3,10 & & & \\
\hline & $\mathrm{X} 3$ & & 3,63 & & \\
\hline \multirow{4}{*}{ Stickiness } & $\mathrm{X} 1$ & 1,87 & & & \\
\hline & $\mathrm{X} 2$ & 2,13 & & & \\
\hline & $\mathrm{X} 4$ & & 2,83 & & \\
\hline & $\mathrm{X} 3$ & & & 3,50 & \\
\hline \multirow{4}{*}{ Preference } & $\mathrm{X} 1$ & 1,60 & & & \\
\hline & $\mathrm{X} 2$ & & 2,17 & & \\
\hline & $\mathrm{X} 4$ & & & 3,00 & \\
\hline & $\mathrm{X} 3$ & & & & 3,60 \\
\hline
\end{tabular}

\subsubsection{Rice Flour-Based Facial Scrub's Aroma}

The analytical result with one-way ANOVA to determine the effect of PPF and OPF proportion on rice flour-based facial scrub's aroma has performed. It showed that $\mathrm{F}$ value $=53.206$ and significant value of 0.000 which results $<0.05$ so it can be concluded that there is an influence between the PPF and OPF proportion on rice flour-based facial scrub's aroma. Orange peel has an important role in giving a fresh aroma, but if the proportion is too much it will produce a pungent aroma. According to the results of research by Safaatul, et al [18] orange peel can produce essential oils that provide aroma. Essential oil is a term used for volatile oil, which consists of a mixture of several substances with different compositions and boiling points.

Essential oils are widely used in industries, such as the soap and cosmetics industry as givers of aroma and taste. While the potato peel has a distinctive aroma that tends not to smell. Characteristics of PPF are yellowish-white color, smooth texture, slightly sweet taste, and has a distinctive fragrant aroma of potato that is not scented [19]. So that when combined with the strong aroma of orange peel, it can produce a balanced, fresh but not pungent aroma. Duncan test result showed that $\mathrm{X} 3$ and $\mathrm{X} 4$ proportion produce a stronger orange peel aroma, there was a fresh potato peel which distinctively not strong compared with other proportion level X1, X2.

\subsubsection{Rice Flour-Based Facial Scrub's Color}

The analytical result with one-way ANOVA to determine the effect of PPF and OPF proportion on rice flour-based facial scrub's color has performed. It showed that $F$ value $=53,145$ and significant value of 0.000 which results $<0.05$ so it can be concluded that there is an influence between the PPF and OPF proportion on rice flour-based facial scrub's color. Yustina and Dena [20] stated that essential oils produced from orange peels have a yellowish color and smell like oranges. Therefore, yellowish color comes from the orange peel, but if the proportion of orange peel is higher, it is likely the yellow color will dominate more so that the resulting color is not appropriate. While, PPF has a younger (not concentrated) yellowish-brown color because the potato peel used in this study is butter potato skin. As Angela [21] stated that butter potato tubers have a light brownish yellow skin color with a sweet and tastier tuber flavor than other potatoes. Duncan's test result showed that X3 proportion produces yellowish-brown color compared with other proportion level X1, X2, and X4. 


\subsubsection{Rice Flour-Based Facial Scrub's Texture}

The analytical result with one-way ANOVA to determine the effect of PPF and OPF proportion on rice flour-based facial scrub's texture showed that $\mathrm{F}$ value $=4,111$ and significant value of 0.008 or $<0.05$. Therefore, it can be concluded that there is an influence of the proportion between the PPF and OPF on rice flour-based facial scrub's texture. The proportion of $\mathrm{X} 3$ gets the highest mean value because it produces a facial scrub with a good texture. In line with that, Fauzi [22] stated that the main function of facial scrub is to remove dead skin cells, a good texture that is rough-textured where if held and smeared there are granules. The texture of OPF tends to be rougher than PPF because it contains a lot of fiber, which if mashed into flour then tends to form granules.

Orange peel consists of flavedo and albedo. Flavedo is part of the outer peel which is located at the bottom of the epidermis layer and contains chromoplast and oil sacs, while the inner skin called albedo is a layer of foam tissue from fibers [23]. While the texture of PPF can be in the form of granules if it is heated because the potato skin contains starch. Starch-modified starches are resistant to high temperatures, stirring, and acidic conditions and have characteristics of granules that are not too swell [24]. The proportion of PPF and OPF that is almost equal (4 $\mathrm{g}$ PPF, 3 g OPF) produces a better texture than the other proportions because the two ingredients have almost the same texture which is rough texture. If the orange peel flour is more then the texture tends to be very rough, but if the proportion of potato skin is more / dominates, the texture is smoother. Therefore, Duncan test result showed that $\mathrm{X} 3$ proportion produces rougher texture compared with other proportion level X1, X2, and X4.

\subsubsection{Rice Flour-Based Facial Scrub's Stickiness}

The analytical result with one-way ANOVA to determine the effect of PPF and OPF proportion on rice flour-based facial scrub's stickiness showed that $F$ value $=28,002$ and significant value of 0.000 or $<0.05$. Therefore, it can be concluded that there is an influence of the proportion between PPF and OPF on rice flour-based facial scrub's stickiness. This is due to potato peel contains starch which has very high adhesion, while orange peel has a low adhesion. Thus, if combined, it will produce good adhesion that can stick well and is easy to remove. Starch adhesiveness on the resulting potato skin is very easy to stick and easy to rub. Starch serves as an adhesive and provides thickness to the physical properties of face scrubs made from potato peels and orange peels.

Besides potato starch derived from potatoes has physical properties that are able to attach objects that contain fat. Including various kinds of microscopic feces and microorganisms [25]. While the adhesiveness of orange peel flour is indeed low according to $\mathrm{Li}$, et al [26] stated that the higher the concentration of orange peel essential oil, the smaller the adhesion. As it is known that orange peel contains lots of essential oils. Duncan test result showed that X3 proportion produces stickiest facial scrub compared with other proportion level X1, X2, and X4.

\subsubsection{Rice Flour-Based Facial Scrub's Preference}

The analytical result with one-way ANOVA to determine the effect of PPF and OPF proportion on rice flour-based facial scrub's preferences showed that $\mathrm{F}$ value $=61,102$ and significant value of 0.000 or $<0.05$. Therefore, it can be concluded that there is an influence of the proportion between PPF and OPF on rice flour-based facial scrub's preferences. This is due to the highest mean value of preference level was 3,6 which can be integrated to 4 . Score 4 has meant a very like which means the proportion of $\mathrm{X} 3$ is the proportion most preferred by panelists because of the aroma of the final product. yellowishbrown. The final product of facial scrub easily adhered to facial skin easily peels off when rubbed has a rough texture and can remove dirt on the surface of facial skin. Duncan test result showed that $\mathrm{X} 3$ proportion produces most preferred facial scrub compared with other proportion level X1, X2, and X4.

\section{CONCLUSION}

According to the experiment and data analysis that carried out on the proportion of PPF and OPF in the rice flour-based facial scrub, we can conclude that potato and orange peel flour proportion affected on aroma, texture, stickiness, color, and preference of rice flour-based face scrub. Overall, the best final product was rice flour face scrub with a proportion of potato and orange peel flour (PPF: OPF) on $4 \mathrm{~g}$ PPF and $3 \mathrm{~g}$ OPF. This study indicated that discharges peel from potato and orange can be transformed into flour, reduce consumed, and industrial waste which has a bad impact on the environment. PPF and OPF can be added in rice flour-based facial scrub in several amounts. Therefore, further research is needed to determine the shelf life of face scrubs.

\section{ACKNOWLEDGMENT}

The authors would like to thank the Universitas Negeri Surabaya which has allowed the author to carry out research in the Cosmetology Laboratory Department of Home Economics, Faculty of Engineering, and supported by alumni of the Department of Home Economics who have assisted this research. 


\section{REFERENCES}

[1] Ministry of Agriculture Data and Information System Center "Annual Productivity Number of Crop Commodities (Ku/Ha) in 2013-2017" Accessed from https://aplikasi2.pertanian.go.id/-bdsp pada 15 September 2019 (2016). Ministry of Agriculture Of The Republic Of Indonesia

[2] Wrochna P. 2016 Modern cosmetology as a source of suffering. Cosmetology. University of Social Sciences and Nature. (Lublin: Poland)

[3] Dzulfakar M A, Kofli N T, Tasirin S M. 2015 An initial study on the influence of natural fermentation on particle size changes duringthe production of bedak sejuk. Journal of Engineering Science and Technology. 10 (Spec. issue4) 71-8.

[4] Kusumanti D P, Sayuti N A, Indarto A S. 2017 Aktivitas Tabir Surya Formula Bedak Dingin Jawa. Indonesian Journal of Pharmaceutical Science and Technology. 10;1(1):01-7.

[5] Umadevi M, Pushpa R, Sampathkumar KP, Bhowmik D. 2012 Rice-traditional medicinal plant in India. Journal of pharmacognosy and phytochemistry. 1;1(1):6-12.

[6] Medina S, Collado J, Ferreres F, Londoño J, Jiménez-Cartagena C, Guy A, Durand T, Galano JM, Gil-Izquierdo A. Valorization strategy of banana passion fruit shell wastes: An innovative source of phytoprostanes and phenolic compounds and their potential use in pharmaceutical and cosmetic industries. J. Food Nutr. Res. 2017;5:801-8.

[7] Saikia AP, Ryakala VK, Sharma P, Goswami $\mathrm{P}$, Bora U. Ethnobotany of medicinal plants used by Assamese people for various skin ailments and cosmetics. Journal of Ethnopharmacology. 2006 Jun 30;106(2):149-57.

[8] Shaheen H, Nazir J, Firdous SS, Khalid AU. Cosmetic ethnobotany practiced by tribal women of Kashmir Himalayas. Avicenna journal of phytomedicine. 2014 Jul;4(4):239.

[9] Afzal S, Mir AK, Tayyaba S. Ethno-botanical studies from Northern Pakistan. J Ayub Med Coll Abbottabad. 2009;21 pp 52-57

[10] Medina S, Collado J, Ferreres F, Londoño J, Jiménez-Cartagena C, Guy A, Durand T, Galano JM, Gil-Izquierdo A. Valorization strategy of banana passion fruit shell wastes: An innovative source of phytoprostanes and phenolic compounds and their potential use in pharmaceutical and cosmetic industries. J. Food Nutr. Res. 2017; 5:801-8.

[11] Sharma K, Mahato N, Cho MH, Lee YR. Converting citrus wastes into value-added products: Economic and environmently friendly approaches. Nutrition. 2017 Feb 1;34: 29-46.

[12] Wu D. Recycle technology for potato peel waste processing: A review. Procedia Environmental Sciences. 2016 Jan 1;31: 103-7.

[13] Yang EJ, Kim SS, Oh TH, Baik JS, Lee NH, Hyun CG. Essential oil of citrus fruit waste attenuates LPS-induced nitric oxide production and inhibits the growth of skin pathogens. Int J Agric Biol 2009;11:791-4

[14] Ministry of Agriculture Data and Information System Center 2017 "Statistics of Annual Fruit and Vegetable Plants Indonesia 2017" Accessed from https://aplikasi2.pertanian.go.id/bdsp pada 15 september 2019. Ministry Of Agriculture Of The Republic Of Indonesia

[15] Lestari, T.B., 2016. Pengaruh citra merek, harga, kualitas produk dan iklan terhadap keputusan pembelian bedak Wardah (studi pada mahasiswi FEBI UIN Walisongo angkatan 2012-2015) (Doctoral dissertation, UIN Walisongo).

[16] Shaheen H, Nazir J, Firdous SS, Khalid AU. Cosmetic ethnobotany practiced by tribal women of Kashmir Himalayas. Avicenna journal of phytomedicine. 2014 Jul;4(4):239.

[17] Gediya SK, Mistry RB, Patel UK, Blessy M, Jain HN. Herbal plants: used as a cosmetics. J. Nat. Prod. Plant Resour. 2011;1(1):24-32.

[18] Safaatul., Munawaroh., Handayani., dan Prima Astuti. 2010. Ekstraksi Minyak Daun Jeruk Purut (Citrus hystrix D.C.) Dengan Pelarut Etanol dan NHeksana. Jurnal Kompetensi Teknik Vol 2, No 1 (2010) Unnes.

[19] Fajiarningsih, Hernawati. 2014. Pengaruh Penggunaan Komposit Tepung Kentang (Solanum Tuberosum L) Terhadap Kualitas Cookies. Semarang: Unnes.

[20] Yustinah dan Dena Fanandara. 2016. Ekstraksi Minyak Atsiri Dari Kulit Jeruk Sebagai Bahan Tambahan Pada Pembuatan Sabun. Jakarta: Teknik 
Kimia Fakultas Teknik Univesitas Muhammadiyah Jakarta.

[21] Angela, Lasmida. 2012. Aktivitas Antioksidan Dan Stabilitas Fisik Gel Anti-Aging Yang Mengandung Ekstrak Air Kentang Kuning. Jakarta:Universitas Indonesia.

[22] Fauzi, Aceng Ridwan dan Nurmalina, Rina. 2012. Merawat Kulit dan Wajah. Jakarta: Gramedia

[23] Santoso, 2015. Kandungan Buah Jeruk Manis. Malang: Universitas Muhammadiyah Malang

[24] Koswara, Sutrisno. 2009. Teknologi Modifikasi Pati. Ebook Pangan

[25] Septiari, Ni Wayan S. 2014. Pengaruh Proporsi Pure Stroberi (Fragaria vesca L) dan Tapioka terhadap Kualitas Masker Wajah Tradisional. Skripsi tidak diterbitkan. Surabaya : Universitas Negeri Surabaya

[26] Li, B. B., Smith, B., \& Hossain, M. M. 2006 Extraction of phenolics from citrus peels: I. Solvent extraction method. Separation and Purification Technology, 48 pp 182-188. 